\title{
Capacity of the Chilean mixed diet to meet the protein and energy requirements of young adult males
}

\author{
BY ENRIQUE YÁÑEZ, R. UAUY, D. BALLESTER, G. BARRERA, \\ N. CHÁVEZ, E. GUZMÁN, M. T. SAITÚA AND I. ZACARÍAS \\ Institute of Nutrition and Food Technology, University of Chile, PO Box 15138, \\ Santiago 11, Chile
}

(Received 27 January 1981 - Accepted 11 August 1981)

\footnotetext{
1. The capacity of the Chilean mixed diet to meet the daily protein and energy needs was tested in eight subjects aged from 20 to 31 years using the nitrogen balance method. This diet was tested at the protein levels of 0.40 . 0.55 and $0.70 \mathrm{~g} / \mathrm{kg}$ body-weight per $\mathrm{d}$.

2. An egg reference diet providing $0-30,0.45$ and $0.60 \mathrm{~g}$ protein $/ \mathrm{kg}$ per $\mathrm{d}$ was also assayed.

3. The mean daily energy intake was $207 \mathrm{~kJ} / \mathrm{kg}$ per d according to subjects' previous intake and activity pattern.

4. The $\mathbf{N}$ balance response to each dietary protein level was taken as a measure of adequacy of protein intake, and regression analyses of $\mathrm{N}$ balance $(Y) v$. $\mathrm{N}$ intake $(X)$ were calculated to estimate protein needs. The equations found were $Y=0.70 X-68.7$ for the egg diet, and $Y=0.74 X-92$ for the mixed diet.

5 . From these equations the mean protein requirements for equilibrium were estimated to be $0.61 \mathrm{~g} / \mathrm{kg}$ for egg and $0.78 \mathrm{~g} / \mathrm{kg}$ for the mixed diet.

6. If the coefficient of variation is 15 , the protein requirement for $\mathrm{N}$ equilibrium of $97.5 \%$ of the population would be $0.8 \mathrm{~g} / \mathrm{kg}$ per $\mathrm{d}$ for egg and $1.0 \mathrm{~g} / \mathrm{kg}$ per $\mathrm{d}$ for the mixed diet.
}

Considerable effort has been dedicated to investigate the capacity of individual proteins such as milk, egg or beef (Clark \& Margen, 1971; Young et al. 1973, 1975) to meet the protein requirements of man. Various criteria have been used by the FAO/WHO Joint Expert Group on Protein Requirements (1965) and by the FAO/WHO Joint Expert Committee on Energy and Protein Requirements (1973) as the basis for establishing recommended protein allowances. These criteria have been criticized by several authors based on more recent information (Garza et al. $1977 a, b$ ) and the recommendations of the FAO/WHO Joint Expert Committee on Energy and Protein Requirements (1973) are presently being re-evaluated. Less attention has been given to the ability of local mixed diets to fulfil protein and energy requirements. This point is highly relevant for developing countries due to the lower biological value of staple proteins in the diet and the high prevalence of environmental enteropathy or infections that affect the protein digestibility and utilization of diets consumed by individuals living in these areas.

The present study was designed to evaluate the capacity of the Chilean mixed diet to meet the protein-energy requirements of young adult men belonging to the low socio-economic groups. The nitrogen balance response to graded levels of dietary protein was used and the intake needed for $\mathrm{N}$ equilibrium determined. The results obtained could be used to establish more realistic protein-energy recommended allowances.

\section{MATERIALS AND METHODS}

Subjects

Eight male subjects whose ages ranged from 20 to 31 years participated in the study. Their initial weights, heights and energy intakes are described in Table 1. All subjects were chosen among volunteers obtained by local advertisement and had monthly incomes lower than US\$150 which corresponds to the lower tercile of the national income distribution (Ministerio de Economia, Fomento y Reconstrucción (Chile), 1968). Their housing, 
Table 1. Physical characteristics and energy intakes of the subjects participating in the study

\begin{tabular}{|c|c|c|c|c|c|}
\hline Subject & $\begin{array}{c}\text { Age } \\
\text { (years) }\end{array}$ & $\begin{array}{l}\mathrm{Wt} \\
(\mathrm{kg})\end{array}$ & $\begin{array}{l}\text { Height } \\
\text { (m) }\end{array}$ & $\begin{array}{l}\mathrm{W} / \mathrm{H} \\
(\%)\end{array}$ & $\begin{array}{l}\text { Energy intake } \\
(\mathrm{kJ}(\mathrm{kcal}) / \mathrm{kg})\end{array}$ \\
\hline JA & 26 & 55.0 & $1 \cdot 61$ & $89 \cdot 5$ & $213(51)$ \\
\hline $\mathrm{HF}$ & 20 & 54.5 & 1.80 & $72 \cdot 4$ & $238(57)$ \\
\hline JB & 25 & 75.0 & 1.77 & $104 \cdot 7$ & $176(42)$ \\
\hline OG & 25 & $60 \cdot 7$ & 1.74 & $86 \cdot 7$ & $205(49)$ \\
\hline SL & 28 & $59 \cdot 0$ & 1.66 & $91 \cdot 1$ & $213(51)$ \\
\hline ML & 30 & $51 \cdot 0$ & 1.62 & $81 \cdot 4$ & $209(50)$ \\
\hline HR & 25 & $60 \cdot 5$ & 1.71 & 88.6 & $197(47)$ \\
\hline ER & 31 & $61 \cdot 5$ & $1 \cdot 70$ & $91 \cdot 3$ & $205(49)$ \\
\hline Mean & $26 \cdot 3$ & $59 \cdot 7$ & $1 \cdot 70$ & $88 \cdot 2$ & $207(49 \cdot 5)$ \\
\hline S.D. & $3 \cdot 4$ & $7 \cdot 2$ & 0.07 & $9 \cdot 2$ & $17 \cdot 3(4 \cdot 2)$ \\
\hline
\end{tabular}

sanitary conditions and educational background were consistent with their incomes and placed them in the low socio-economic groups. The individuals were free of abnormalities detectable by medical examination and laboratory evaluation which included haematocrit, haemoglobin, total and differential white blood count, measurement of serum transaminase activities and complete urinalysis. Subjects continued their normal daily routines, including their usual pattern of activity but refrained from participating in competitive sports during the study. The individuals slept in the metabolic unit of INTA's Clinical Research Center. The experimental procedures were reviewed and approved by INTA's Ethics Committee which supervises the use of humans as experimental subjects, and by the Research Committee. The individuals were fully informed of the nature of the study and signed consent forms stating that their participation was on a voluntary basis. In addition they were free to terminate their participation in the study at any time. All subjects remained under the supervision of a physician and a nurse throughout the duration of the study. Subject M L completed only the egg diet and then voluntarily left.

\section{Experimental diets}

The subjects were given a 'Chilean mixed diet' designed according to available dietary survey information of a typical Chilean diet for the low income group (Morán, 1976; Ministerio de Salud (Chile), 1976). The composition of this diet is given in Table 2. Protein levels of $0.40,0.55$ and $0.70 \mathrm{~g} / \mathrm{kg}$ body-weight per $\mathrm{d}$ of the mixed diet were fed to all subjects. In addition an egg reference diet which provided $0.30,0.45$ and $0.60 \mathrm{~g}$ protein $/ \mathrm{kg}$ per d was fed at isoenergetic intakes. The composition of the egg diet is also given in Table 2. The daily energy intake of each subject was calculated after a prospective study of their customary diet by the ' $24 \mathrm{~h}$ dietary recall' method for fifteen consecutive days and also based on their energy expenditure according to the pattern of their usual energy intake and activity. Vitamin and mineral supplements were provided daily to meet or exceed recommended dietary allowances ((US) National Academy of Sciences, 1974). Individual ingredients and preparations were analyzed for their $\mathrm{N}$ content by the Kjeldahl method (Association of Official Analytical Chemists, 1970) using a macro-digestion procedure followed by a semi-microdistillation of the ammonia produced into boric acid $(20 \mathrm{~g} / 1)$ containing a mixed indicator (Markham, 1942).

Each experimental period started with a protein free diet for $1 \mathrm{~d}$ and was followed by $10 \mathrm{~d}$ on the experimental diet. The sequence of protein levels was randomly assigned for each individual. Three isoenergetic-isonitrogenous meals were provided at $08.00,13.00$ and 19.00 
Table 2. Composition $(\mathrm{g} / \mathrm{d})$ of experimental diets used for study of protein requirements in young Chilean men

\begin{tabular}{|c|c|c|}
\hline \multirow[b]{2}{*}{ Ingredients } & \multicolumn{2}{|c|}{ Level of intake $(\mathrm{g})$} \\
\hline & Mixed diet & Egg diet \\
\hline Whole, dried egg powder & - & $34 \cdot 3$ \\
\hline Sucrose & $106 \cdot 4$ & $114 \cdot 0$ \\
\hline Wheat flour & $145 \cdot 1$ & - \\
\hline Margarine & $54 \cdot 1$ & $67 \cdot 1$ \\
\hline Dried skim milk & 27.9 & - \\
\hline Rice & $61 \cdot 4$ & - \\
\hline Maize starch & - & $246 \cdot 9$ \\
\hline Bean soup powder & $46 \cdot 0$ & - \\
\hline Vegetable oil (ml) & $32 \cdot 7$ & $70 \cdot 5$ \\
\hline Potato flakes & $112 \cdot 0$ & - \\
\hline Soup flavouring & & $2 \cdot 0$ \\
\hline Apricot marmalade & $15 \cdot 0$ & - \\
\hline Orange-flavoured beverage & $23 \cdot 6$ & 37.5 \\
\hline Lemon-flavoured beverage & - & 37.5 \\
\hline Water $(\mathrm{ml})$ & 1200 & 1754 \\
\hline Vitamin-mineral supplement ${ }^{*}$ & & \\
\hline
\end{tabular}

Mixed diet: wheat-flour bread, rice-milk dessert, bean soup, potato flakes; intake is given for a $61 \mathrm{~kg}$ subject.

Egg diet: maize-starch bread, maize-starch soup, omelette, liquid egg formula, maize-starch dessert, protein-free cookies; intake is given for a $60 \mathrm{~kg}$ subject.

* Multivitamin-mineral supplement (Laboratories Pfizer de Chile, Santiago, Chile). One tablet supplied: retinol $1500 \mu \mathrm{g}$, cholecalciferol $25 \mu \mathrm{g}$, thiamin I mg, ribofiavin $2 \mathrm{mg}$, pyridoxine $1 \mathrm{mg}$, cyanocobalamin $2 \mu \mathrm{g}$, ascorbic acid $50 \mathrm{mg}$, nicotinamide $12 \mathrm{mg}$, calcium pantothenate $2 \mathrm{mg}$, copper (as $\mathrm{CuO}$ ) $70 \mathrm{mg}$, iodine (as KI) $50 \mu \mathrm{g}$, iron $1 \mathrm{mg}$, potassium (as $\mathrm{KI}$ ) $16 \mu \mathrm{g}$, manganese (as $\mathrm{MnCO}_{3}$ ) $29 \mu \mathrm{g}$, magnesium (as $\mathrm{MgO}$ ) $108 \mu \mathrm{g}$, zinc (as $\mathrm{ZnO}$ ) $71 \mu \mathrm{g}$.

hours and consumed under the close supervision of a dietitian. The protein sources during the mixed diet period were distributed as equally as possible in the three daily meals. Breaks of $3 \mathrm{~d}$ duration were interposed between periods during which individuals consumed a free-choice diet. A similar design was used to test both proteins.

\section{Samples and measurements}

Complete $24 \mathrm{~h}$ urine collections under sulphuric acid $(100 \mathrm{ml} / \mathrm{l})$ were made throughout the study taking a portion for analysis of total urea-N, and creatinine (Tietz, 1970). An extra sample was frozen for possible future use. Faeces were collected daily and pooled for the last $8 \mathrm{~d}$ of each dietary period and were identified by the use of autoclaved brilliant blue and carmine red markers (Lutwak \& Burton, 1964). $\mathrm{N}$ balance was calculated by subtracting the mean daily urine and faecal $\mathbf{N}$ excretion from the daily $\mathbf{N}$ intake. For integumental and miscellaneous $\mathrm{N}$ losses the value of $5 \mathrm{mg} \mathrm{N} / \mathrm{kg}$ body-weight per $\mathrm{d}$ was used (Calloway et al. 1971). Body-weights were obtained daily at 08.00 hours after the subjects had voided the first morning urine but before they had eaten breakfast and with minimal clothing, using scales accurate to the nearest $50 \mathrm{~g}$. Before initiating the study and at the end of the lowest and highest protein test periods a fasting blood sample was taken from an antecubital vein at $\mathbf{0 8 . 0 0}$ hours and analyzed for serum total protein, albumin, urea, transaminases and complete blood count. In addition anthropometric indices which included height, bodyweight, waist, gluteal and mid-upper arm circumference, triceps fat fold thickness and subscapular fat fold thickness were obtained at the beginning and end of each dietary level. 


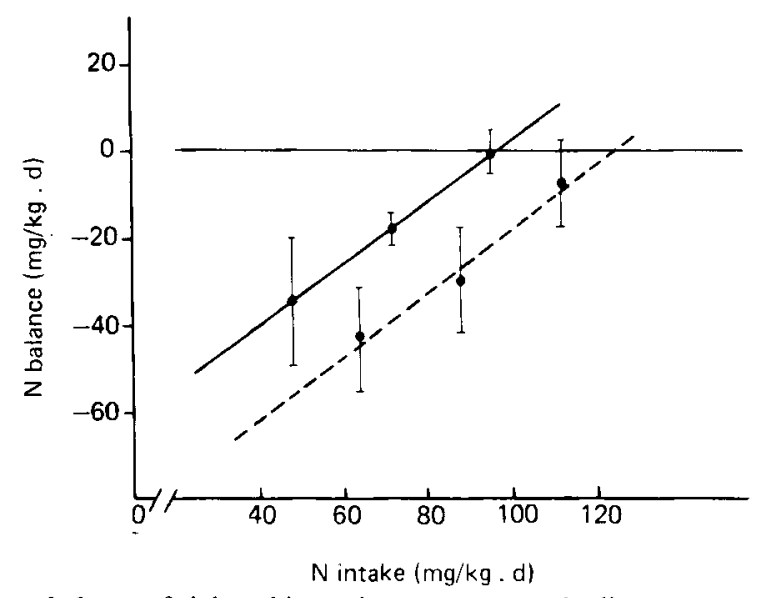

Fig. 1. Mean nitrogen balance of eight subjects given an egg protein diet ( - $)$ and a Chilean mixed diet (---). For details of diets, see p. 2 and Table 2. Points are mean values with standard deviations represented by vertical bars.

Equations: egg diet $Y=0.70 X-68.7$, Chilean diet $Y=0.74 X-92$.

\section{Statistical analyses}

Statistical processing of values included the usual parametric analysis based on individual values for each subject. Regression and correlation were calculated and the significance of differences between means was tested by Student's $t$ test or ANOVA using the F values (Snedecor \& Cochran, 1967).

\section{RESULTS}

Minor weight changes were observed during the diet periods with a mean weight change of $0.055 \mathrm{~kg}$ when comparing initial and final weights. Results of anthropometric changes are summarized in Table 3. During both egg and mixed-diet periods the urinary total $\mathrm{N}$ excretion was greater with increasing $\mathrm{N}$ intakes as can be seen in Tables 4 and 5 . The urinary $\mathrm{N}$ increased gradually from $59 \mathrm{mg} / \mathrm{kg}$ per $\mathrm{d}$ for the lowest level of $\mathrm{N}$ intake of the egg diet to $73 \mathrm{mg} / \mathrm{kg}$ per $\mathrm{d}$ for the $0.6 \mathrm{~g}$ protein $/ \mathrm{kg}$ per $\mathrm{d}$ level. A comparable result was obtained for the mixed diet. In this instance the urinary $\mathrm{N}$ output was $69 \mathrm{mg} / \mathrm{kg}$ per $\mathrm{d}$ at the $0.4 \mathrm{~g}$ protein $/ \mathrm{kg}$ per d level increasing to 77 and $80 \mathrm{mg} / \mathrm{kg}$ per $\mathrm{d}$ for the 0.55 and $0.7 \mathrm{~g}$ protein $/ \mathrm{kg}$ per $d$ levels. Urinary $\mathrm{N}$ values were significantly higher while subjects consumed the mixed $\operatorname{diet}(P<0 \cdot 01)$. No correlation was found between faecal- $\mathrm{N}$ output and the level of protein intake for either protein. However, the magnitude of faecal-N excretion was significantly higher on the mixed diet $(P<0.001)$. The excretion was close to $18 \mathrm{mg} \mathrm{N} / \mathrm{kg}$ per $\mathrm{d}$ for men on the egg diet and $34 \mathrm{mg} \mathrm{N} / \mathrm{kg}$ per $\mathrm{d}$ for men on the mixed diet, practically twice the value obtained with egg. This difference gave significantly lower values for the apparent $\mathrm{N}$ digestibility of the mixed diet $(P<0.001)$.

Estimated true $\mathrm{N}$ balance improved with increasing $\mathrm{N}$ intake for both diets. For the egg diet it was $-34.6 \mathrm{mg} / \mathrm{kg}$ per d at $48 \mathrm{mg} \mathrm{N} / \mathrm{kg}$ per d, $-18.6 \mathrm{mg} \mathrm{N} / \mathrm{kg}$ per d at $72 \mathrm{mg} \mathrm{N} / \mathrm{kg}$ per $\mathrm{d}$ and $-0.8 \mathrm{mg} \mathrm{N} / \mathrm{kg}$ per $\mathrm{d}$ at an intake of $96 \mathrm{mg} \mathrm{N} / \mathrm{kg}$ per $\mathrm{d}$ (Table 4). All subjects were in negative $\mathrm{N}$ balance at 48 and $72 \mathrm{mg} \mathrm{N} / \mathrm{kg}$ per $\mathrm{d}$ intakes, but three of the eight subjects achieved positive $\mathrm{N}$ balance at the $96 \mathrm{mg} \mathrm{N} / \mathrm{kg}$ per $\mathrm{d}$ of egg- $\mathrm{N}$ intake. For the mixed diet (Table 5) $\mathrm{N}$ balance was $-43.4 \mathrm{mg} / \mathrm{kg}$ per $\mathrm{d}$ at an intake of $64 \mathrm{mg} \mathrm{N} / \mathrm{kg}$ per $\mathrm{d},-30.0 \mathrm{mg} / \mathrm{kg}$ per $\mathrm{d}$ at an intake of $88 \mathrm{mg} \mathrm{N} / \mathrm{kg}$ per $\mathrm{d}$ and $-8.0 \mathrm{mg} \mathrm{N} / \mathrm{kg}$ per $\mathrm{d}$ at an 
Table 3. Anthropometric changes of subjects participating in the study

\begin{tabular}{|c|c|c|c|c|c|c|c|}
\hline & Subjects & $\begin{array}{c}\text { Body-wt } \\
(\mathrm{kg})\end{array}$ & $\begin{array}{l}\text { Waist } \\
(\mathrm{mm})\end{array}$ & $\begin{array}{c}\text { Gluteal } \\
\text { circumference } \\
(\mathrm{mm})\end{array}$ & $\begin{array}{l}\text { Mid-upper } \\
\text { left } \\
\text { arm } \\
\text { circumference } \\
(\mathrm{mm})\end{array}$ & $\begin{array}{l}\text { Left triceps } \\
\text { fat fold } \\
(\mathrm{mm})\end{array}$ & $\begin{array}{c}\text { Left } \\
\text { subscapular } \\
\text { fat fold } \\
\text { (mm) }\end{array}$ \\
\hline JA & $\begin{array}{l}\text { Initial } \\
\text { Change }\end{array}$ & $\begin{array}{l}55 \cdot 0 \\
-1 \cdot 22\end{array}$ & $\begin{array}{l}720 \\
-5\end{array}$ & $\begin{array}{r}850 \\
-10\end{array}$ & $\begin{array}{l}260 \\
-5\end{array}$ & $\begin{array}{l}5 \cdot 6 \\
0 \cdot 2\end{array}$ & $\begin{array}{l}8 \cdot 4 \\
0\end{array}$ \\
\hline $\mathrm{HF}$ & $\begin{array}{l}\text { Initial } \\
\text { Change }\end{array}$ & $\begin{array}{l}54 \cdot 5 \\
+1 \cdot 35\end{array}$ & $\begin{array}{r}720 \\
10\end{array}$ & $\begin{array}{r}845 \\
15\end{array}$ & $\begin{array}{r}250 \\
0\end{array}$ & $\begin{array}{l}5 \cdot 0 \\
0 \cdot 2\end{array}$ & $\begin{array}{l}6 \cdot 4 \\
0\end{array}$ \\
\hline JB & $\begin{array}{l}\text { Initial } \\
\text { Change }\end{array}$ & $\begin{array}{l}75 \cdot 0 \\
-0 \cdot 27\end{array}$ & $\begin{array}{r}900 \\
-10\end{array}$ & $\begin{array}{r}960 \\
0\end{array}$ & $\begin{array}{r}310 \\
0\end{array}$ & $\begin{array}{l}8 \cdot 4 \\
0\end{array}$ & $\begin{array}{r}16 \cdot 2 \\
0.2\end{array}$ \\
\hline OG & $\begin{array}{l}\text { Initial } \\
\text { Change }\end{array}$ & $\begin{array}{l}60 \cdot 7 \\
+0.67\end{array}$ & $\begin{array}{r}800 \\
15\end{array}$ & $\begin{array}{r}895 \\
15\end{array}$ & $\begin{array}{r}255 \\
10\end{array}$ & $\begin{array}{l}5 \cdot 5 \\
0.5\end{array}$ & $\begin{array}{r}11 \cdot 2 \\
0.2\end{array}$ \\
\hline SL & $\begin{array}{l}\text { Initial } \\
\text { Change }\end{array}$ & $\begin{array}{l}59 \cdot 0 \\
-0.22\end{array}$ & $\begin{array}{r}810 \\
0\end{array}$ & $\begin{array}{r}910 \\
0\end{array}$ & $\begin{array}{r}255 \\
0\end{array}$ & $\begin{array}{l}5 \cdot 2 \\
0\end{array}$ & $\begin{array}{l}8.6 \\
0.2\end{array}$ \\
\hline HR & $\begin{array}{l}\text { Initial } \\
\text { Change }\end{array}$ & $\begin{array}{l}60 \cdot 5 \\
+0.27\end{array}$ & $\begin{array}{r}790 \\
10\end{array}$ & $\begin{array}{r}900 \\
10\end{array}$ & $\begin{array}{r}245 \\
5\end{array}$ & $\begin{array}{l}6.2 \\
0.2\end{array}$ & $\begin{array}{r}10.6 \\
-0.2\end{array}$ \\
\hline ER & $\begin{array}{l}\text { Initial } \\
\text { Change }\end{array}$ & $\begin{array}{l}61.5 \\
-0.97\end{array}$ & $\begin{array}{r}800 \\
-20\end{array}$ & $\begin{array}{r}880 \\
0\end{array}$ & $\begin{array}{r}270 \\
0\end{array}$ & $\begin{array}{r}5.6 \\
-0.2\end{array}$ & $\begin{array}{r}7.4 \\
-0.4\end{array}$ \\
\hline Mear & $\begin{array}{l} \pm \text { SD } \\
\text { Initial } \\
\text { Change }\end{array}$ & $\begin{array}{r}60.9 \pm 6.8 \\
0.055 \pm 0.9\end{array}$ & $\begin{array}{r}791 \pm 61 \\
0.0 \pm 13\end{array}$ & $\begin{array}{c}891 \pm 39 \\
4 \pm 9\end{array}$ & $\begin{array}{c}264 \pm 22 \\
1 \pm 4\end{array}$ & $\begin{array}{l}5 \cdot 9 \pm 1.2 \\
0.1 \pm 0.2\end{array}$ & $\begin{array}{l}9 \cdot 8 \pm 3 \cdot 3 \\
0 \cdot 0 \pm 0 \cdot 2\end{array}$ \\
\hline
\end{tabular}

intake of $112 \mathrm{mg} \mathrm{N} / \mathrm{kg}$ per d. All subjects were in negative $\mathrm{N}$ balance at intakes of 64 and $88 \mathrm{mg} \mathrm{N} / \mathrm{kg}$ mixed diet. Only one of the seven subjects achieved positive $\mathrm{N}$ balance at the $0.7 \mathrm{~g}$ protein $/ \mathrm{kg}$ per $\mathrm{d}$ intake. Results of regression analyses of $\mathrm{N}$ balance on $\mathrm{N}$ intake are shown in the following equations (SE of slope and intercept given in parentheses) and Fig. 1:

$$
\begin{aligned}
\text { egg diet } & Y=0.70( \pm 0.09) X-68.7( \pm 6.6) n 8, r 0.80 \\
\text { mixed diet } & Y=0.74( \pm 0.12) X-92( \pm 10.6) n 7, r 0.81
\end{aligned}
$$

From these equations the mean $N$ requirements for equilibrium was estimated to be $98 \mathrm{mg}$ $\mathrm{N} / \mathrm{kg}$ or $0.61 \mathrm{~g}$ protein $/ \mathrm{kg}$ for the egg diet, and $124 \mathrm{mg} \mathrm{N} / \mathrm{kg}$ or $0.78 \mathrm{~g}$ protein $/ \mathrm{kg}$ for the mixed diet. Based on the confidence limits about the regression, the recommended intake to satisfy the $\mathrm{N}$ balance requirements for $97.5 \%$ of the subjects was computed to be $1.1 \mathrm{~g} / \mathrm{kg}$ for egg and $1.5 \mathrm{~g} / \mathrm{kg}$ for the mixed diet (Rand et al. 1977; United Nations University, 1979). If one assumes a smaller variance if a larger group were evaluated considering a coefficient of variation of 15 , the requirements for $\mathrm{N}$ balance of $97.5 \%$ of the population would be $0.8 \mathrm{~g}$ for egg and $1.0 \mathrm{~g}$ protein $/ \mathrm{kg}$ per $\mathrm{d}$ for the mixed diet.

The average true digestibility of egg protein was $0.826,0.891$ and 0.928 for the three protein levels studied. The protein digestibility of the mixed diet was significantly lower $(P<0.001)$ than that of egg protein and increased from 0.714 to 0.771 and 0.835 with increasing levels of $\mathrm{N}$ intake.

Table 6 summarizes changes in serum total protein, albumin, blood urea-N (BUN) and serum glutamic-oxaloacetic transaminase (EC 2.6.1.1; SGOT) and glutamic pyruvate transaminase (EC 2 6 1 1.2; SGPT). Significant changes related to the diets were evident for total serum protein and albumin. Values remained stable in all the individuals while consuming the egg diet, but a significant decrease was observed with the mixed diet. A significant change was noted in BUN which decreased from an initial value of 137 to 
Table 4. Nitrogen balance ( $\mathrm{mg} / \mathrm{kg}$ per $\mathrm{d})$ and $\mathrm{N}$ digestibility of individual subjects given an egg diet at three dietary levels of $N$ intake

\begin{tabular}{|c|c|c|c|c|c|}
\hline $\begin{array}{c}\mathrm{N} \text { intake } \\
(\mathrm{mg} / \mathrm{kg} \text { per } \mathrm{d})\end{array}$ & Subjects & Urinary $\mathbf{N}$ & Faecal N & $\mathbf{N}$ balance* & $\begin{array}{l}\text { Apparent } \\
\text { Digestibility }\end{array}$ \\
\hline \multirow[t]{2}{*}{48} & $\begin{array}{l}\text { JA } \\
\text { HF } \\
\text { JB } \\
\text { OG } \\
\text { SL } \\
\text { ML } \\
\text { HR } \\
\text { ER }\end{array}$ & $\begin{array}{l}67 \cdot 8 \\
50 \cdot 8 \\
49 \cdot 3 \\
53 \cdot 4 \\
48 \cdot 6 \\
77 \cdot 0 \\
70 \cdot 1 \\
54 \cdot 4\end{array}$ & $\begin{array}{r}19 \cdot 6 \\
13 \cdot 3 \\
9.2 \\
18 \cdot 5 \\
24.0 \\
21 \cdot 8 \\
25.0 \\
18.1\end{array}$ & $\begin{array}{l}-44.4 \\
-21.1 \\
-15.5 \\
-28.9 \\
-29.6 \\
-55.8 \\
-52.1 \\
-29.5\end{array}$ & $\begin{array}{l}0.592 \\
0.723 \\
0.808 \\
0.615 \\
0.500 \\
0.546 \\
0.479 \\
0.623\end{array}$ \\
\hline & $\begin{array}{l}\text { Mean } \\
\text { SD }\end{array}$ & $\begin{array}{l}58.9 \\
11 \cdot 0\end{array}$ & $\begin{array}{r}18 \cdot 7 \\
5 \cdot 3\end{array}$ & $\begin{array}{r}-34.6 \\
14.6\end{array}$ & $\begin{array}{l}0.611 \\
0.111\end{array}$ \\
\hline \multirow[t]{2}{*}{72} & $\begin{array}{l}\text { JA } \\
\text { HF } \\
\text { JB } \\
\text { OG } \\
\text { SL } \\
\text { ML } \\
\text { HR } \\
\text { ER }\end{array}$ & $\begin{array}{l}62 \cdot 8 \\
78 \cdot 3 \\
72 \cdot 8 \\
67 \cdot 1 \\
66 \cdot 3 \\
62 \cdot 5 \\
68 \cdot 1 \\
63 \cdot 8\end{array}$ & $\begin{array}{l}19 \cdot 1 \\
14 \cdot 6 \\
16 \cdot 0 \\
18 \cdot 2 \\
17 \cdot 5 \\
20 \cdot 0 \\
15 \cdot 7 \\
22 \cdot 2\end{array}$ & $\begin{array}{l}-14.9 \\
-25.9 \\
-21.8 \\
-18.3 \\
-16.8 \\
-15.5 \\
-16.8 \\
-19.0\end{array}$ & $\begin{array}{l}0.735 \\
0.797 \\
0.778 \\
0.747 \\
0.757 \\
0.722 \\
0.788 \\
0.692\end{array}$ \\
\hline & $\begin{array}{l}\text { Mean } \\
\text { SD }\end{array}$ & $\begin{array}{r}67 \cdot 7 \\
5 \cdot 4\end{array}$ & $\begin{array}{r}17.9 \\
2.5\end{array}$ & $\begin{array}{r}-18 \cdot 6 \\
3 \cdot 7\end{array}$ & $\begin{array}{l}0.752 \\
0.36\end{array}$ \\
\hline \multirow[t]{2}{*}{96} & $\begin{array}{l}\text { JA } \\
\text { HF } \\
\text { JB } \\
\text { OG } \\
\text { SL } \\
\text { ML } \\
\text { HR } \\
\text { ER }\end{array}$ & $\begin{array}{l}72 \cdot 0 \\
67 \cdot 4 \\
72 \cdot 2 \\
71 \cdot 6 \\
77 \cdot 5 \\
72 \cdot 6 \\
74.5 \\
75 \cdot 4\end{array}$ & $\begin{array}{l}22 \cdot 6 \\
15 \cdot 8 \\
14 \cdot 5 \\
18 \cdot 4 \\
20 \cdot 8 \\
20 \cdot 9 \\
18 \cdot 9 \\
19 \cdot 4\end{array}$ & $\begin{array}{l}-3.6 \\
+7.8 \\
+4.3 \\
+1.0 \\
-7.3 \\
-2.5 \\
-2.4 \\
-3.8\end{array}$ & $\begin{array}{l}0.765 \\
0.835 \\
0.849 \\
0.808 \\
0.783 \\
0.782 \\
0.803 \\
0.798\end{array}$ \\
\hline & $\begin{array}{l}\text { Mean } \\
\text { SD }\end{array}$ & $\begin{array}{r}72 \cdot 9 \\
3.0\end{array}$ & $\begin{array}{r}18 \cdot 9 \\
2 \cdot 7\end{array}$ & $\begin{array}{r}-0 \cdot 8 \\
4 \cdot 9\end{array}$ & $\begin{array}{l}0.802 \\
0.28\end{array}$ \\
\hline
\end{tabular}

* Estimated 'true' balance, assuming $5 \mathrm{mg} \mathrm{N} / \mathrm{kg}$ per $\mathrm{d}$ for integumental and miscellaneous losses.

approximately $70 \mathrm{~g} / 1$ for both the egg and mixed diets. Non-significant changes were observed in SGOT values for both protein sources. Values for SGPT decreased from the initial levels but were stable during both experimental-diet periods.

\section{DISCUSSION}

Our results clearly suggest that the present FAO/WHO safe recommended allowance for adult men does not cover protein requirements of nearly all healthy individuals. In our subjects $0.6 \mathrm{~g}$ of egg reference protein $/ \mathrm{kg}$ per $\mathrm{d}$ was sufficient for $\mathrm{N}$ balance in less than half the group. The extrapolation for $\mathrm{N}$ equilibrium based on the regression gave an intake of $0.8 \mathrm{~g} / \mathrm{kg}$ per $\mathrm{d}$ as enough for the majority if one used the customary coefficient of variation for these types.of measurements.

Faecal $\mathrm{N}$ remained fairly constant in the submaintenance range of intakes and digestibility appeared to improve with higher $\mathbf{N}$ intake. Faecal $\mathbf{N}$ while subjects consumed the egg diet was slightly higher than reported values for subjects from developed countries. Faecal $\mathbf{N}$ obtained on the mixed diet was significantly higher and accounts in an important part for the low biological value of the mixed diet. 
Table 5. Nitrogen balance $(\mathrm{mg} / \mathrm{kg}$ per $d)$ and $N$ digestibility of individual subjects given a Chilean mixed diet at three dietary levels of $N$ intake

\begin{tabular}{|c|c|c|c|c|c|}
\hline $\begin{array}{l}\text { N intake } \\
\text { (mg/kg per d) }\end{array}$ & Subjects & Urinary $\mathbf{N}$ & Faecal $\mathbf{N}$ & N balance* & $\begin{array}{l}\text { Apparent } \\
\text { digestibility }\end{array}$ \\
\hline \multirow[t]{2}{*}{64} & $\begin{array}{l}\text { JA } \\
\text { HF } \\
\text { JB } \\
\text { OG } \\
\text { SL } \\
\text { HR } \\
\text { ER }\end{array}$ & $\begin{array}{l}71 \cdot 8 \\
58.6 \\
55 \cdot 7 \\
84 \cdot 7 \\
69 \cdot 4 \\
74 \cdot 6 \\
69 \cdot 1\end{array}$ & $\begin{array}{l}36 \cdot 7 \\
29 \cdot 1 \\
31 \cdot 2 \\
30.8 \\
44.9 \\
38.8 \\
29 \cdot 2\end{array}$ & $\begin{array}{l}-49 \cdot 5 \\
-28 \cdot 7 \\
-27 \cdot 9 \\
-56 \cdot 5 \\
-55 \cdot 3 \\
-46 \cdot 4 \\
-39 \cdot 3\end{array}$ & $\begin{array}{l}0.426 \\
0.545 \\
0.512 \\
0.519 \\
0.298 \\
0.394 \\
0.544\end{array}$ \\
\hline & $\begin{array}{l}\text { Mean } \\
\text { SD }\end{array}$ & $\begin{array}{r}69 \cdot 1 \\
9 \cdot 8\end{array}$ & $\begin{array}{r}33.2 \\
5.7\end{array}$ & $\begin{array}{r}-43 \cdot 4 \\
11 \cdot 8\end{array}$ & $\begin{array}{l}0.462 \\
0.093\end{array}$ \\
\hline \multirow[t]{2}{*}{88} & $\begin{array}{l}\text { JA } \\
\text { HF } \\
\text { JB } \\
\text { OG } \\
\text { SL } \\
\text { HR } \\
\text { ER }\end{array}$ & $\begin{array}{l}75 \cdot 2 \\
69 \cdot 5 \\
65 \cdot 4 \\
66 \cdot 6 \\
82.8 \\
96.0 \\
81.9\end{array}$ & $\begin{array}{l}40.0 \\
38.8 \\
30.5 \\
34.3 \\
44.9 \\
30.8 \\
34.4\end{array}$ & $\begin{array}{l}-32.2 \\
-25 \cdot 3 \\
-12.9 \\
-17.9 \\
-44.7 \\
-43.8 \\
-33.3\end{array}$ & $\begin{array}{l}0.545 \\
0.559 \\
0.575 \\
0.610 \\
0.431 \\
0.650 \\
0.609\end{array}$ \\
\hline & $\begin{array}{l}\text { Mean } \\
\text { SD }\end{array}$ & $\begin{array}{l}76 \cdot 8 \\
11.0\end{array}$ & $\begin{array}{r}36 \cdot 2 \\
5 \cdot 3\end{array}$ & $\begin{array}{r}-30 \cdot 0 \\
12 \cdot 1\end{array}$ & $\begin{array}{l}0.568 \\
0.070\end{array}$ \\
\hline \multirow[t]{2}{*}{112} & $\begin{array}{l}\text { JA } \\
\text { HF } \\
\text { JB } \\
\text { OG } \\
\text { SL } \\
\text { HR } \\
\text { ER }\end{array}$ & $\begin{array}{l}84 \cdot 1 \\
78 \cdot 1 \\
64 \cdot 2 \\
83 \cdot 4 \\
73 \cdot 4 \\
99 \cdot 9 \\
80 \cdot 0\end{array}$ & $\begin{array}{l}35.4 \\
35 \cdot 0 \\
32.5 \\
32.6 \\
43 \cdot 4 \\
28 \cdot 7 \\
34.4\end{array}$ & $\begin{array}{r}-12.5 \\
-6.1 \\
+10.3 \\
-9.0 \\
-9.8 \\
-21.6 \\
-7.4\end{array}$ & $\begin{array}{l}0.684 \\
0.687 \\
0.710 \\
0.709 \\
0.612 \\
0.744 \\
0.693\end{array}$ \\
\hline & $\begin{array}{l}\text { Mean } \\
\text { SD }\end{array}$ & $\begin{array}{l}80.4 \\
11.0\end{array}$ & $\begin{array}{r}34 \cdot 6 \\
4 \cdot 5\end{array}$ & $\begin{array}{r}-8.0 \\
9.6\end{array}$ & $\begin{array}{l}0.691 \\
0.040\end{array}$ \\
\hline
\end{tabular}

* Estimated 'true' balance, assuming $5 \mathrm{mg} \mathrm{N} / \mathrm{kg}$ per $\mathrm{d}$ for integumental and miscellaneous losses.

The evaluation of protein digestibility in our subjects did not include specific measurements of the effect of dietary fibre and its interaction with the intestinal microflora. Nevertheless

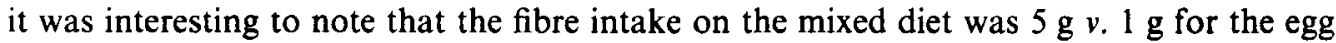
diet. All subjects had evidence of non-pathogenic intestinal microbiological contamination but none showed abnormalities in stool pattern or consistency. Further studies on the effects of fibre and microbiological intestinal environment are presently in progress.

The object of this study did not include the assessment of the effects of possible vitamin and mineral deficiences on protein utilization. Therefore we used supplements of these compounds to assure that they were not limiting.

The $\mathbf{N}$ retention as defined by net protein utilization (NPU) (fraction of $\mathbf{N}$ intake retained) increased with higher protein intakes. This is in clear contradiction of information from other authors (Young et al. 1975; Kishi et al. 1978), which shows that at greater intakes NPU decreases and the slope of the regression between $\mathrm{N}$ intake and $\mathrm{N}$ balance becomes smaller. As expected the calculated NPU of the mixed diet compared to egg is lower. The mean NPU for the egg diet ranged from 0.49 to 0.60 and for the mixed diet from 0.22 to 0.45 at lowest and highest levels of $\mathrm{N}$ intake respectively. The NPU for the mixed diet relative to egg ranged from $44 \%$ at lowest to $75 \%$ at highest level of protein intake.

Considerations of energy balance are critical to $\mathrm{N}$ balance studies. Our subjects consumed 
E. YÁÑEZ AND OTHERS

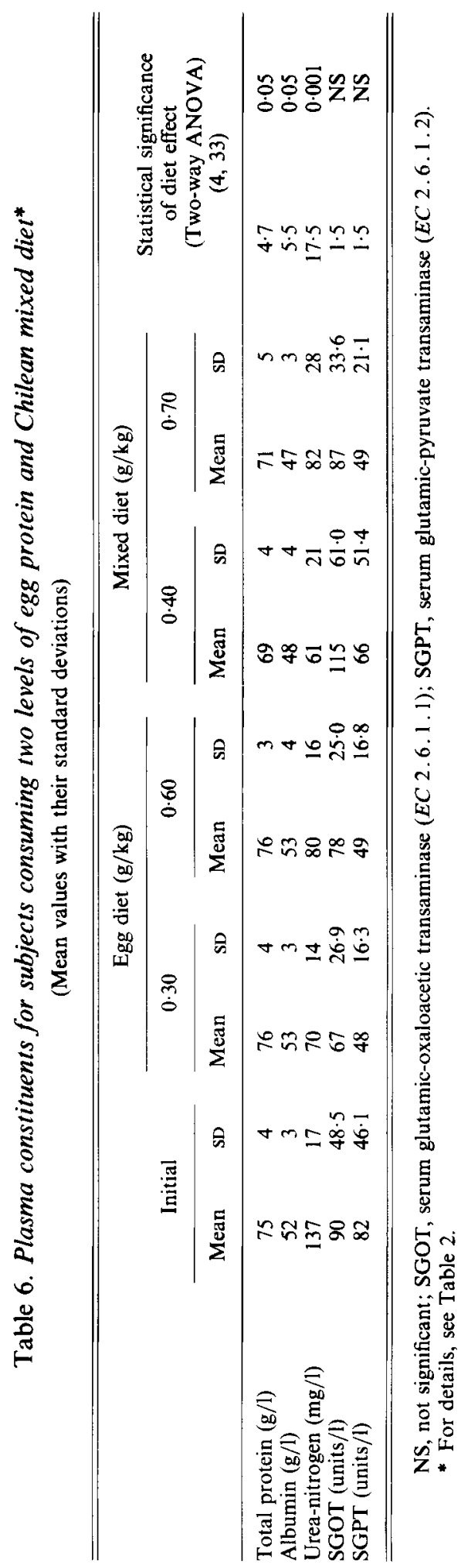


a mean of $207 \mathrm{~kJ}$ (49.5 kcal)/ $\mathrm{kg}$ which is higher than customary for these studies but is in agreement with the observed intakes and the activity pattern for these individuals. The anthropometric indices suggest that our subjects are leaner than those of the International Standards (Jelliffe, 1966), and hence a higher energy intake on a body-weight basis can be expected. There was a negative correlation $(r-0 \cdot 89)$ between weight: height $(\mathrm{W} / \mathrm{H})$ index and energy intake required to maintain stable body-weight. From this regression the estimated energy intake for a subject with a W/H of $100 \%$ is $187 \mathrm{~kJ}(44.7 \mathrm{kcal}) / \mathrm{kg}$. This is similar to required energy intakes in studies of healthy normal Caucasian subjects. The minor non-significant changes on indicators of energy balance such as weight, body circumferences and skinfold measurements suggest that our subjects were close to equilibrium and that the high energy intakes are accountable by body composition and activity pattern of our subjects.

Based on the $\mathrm{N}$ balance regression on the egg diet the extrapolated mean obligatory $\mathrm{N}$ losses are $69 \mathrm{mg} \mathrm{N} / \mathrm{kg}$ per $\mathrm{d}$ which is similar to those estimated from the available values corrected by the $30 \%$ factor for decreased efficiency of utilization within the maintenance range. Yet the factorial method will underestimate $\mathbf{N}$ intake for equilibrium since true mean retention for egg protein is only $53 \%$ which means that a correction factor of $88 \%$ would be needed to extrapolate $\mathrm{N}$ intake for balance correctly.

The biochemical changes observed suggest that for egg, in spite of low intakes and negative $\mathrm{N}$ balance, the only significant change is a decreased urea pool. For the mixed diet, even on the highest protein intake, albumin is lower than either initial values or those noted while subjects consumed egg. Also lower serum urea levels are seen on the mixed diet but these are not different from those on the egg diet. The slight non-significant rise on SGOT while subjects were on the lowest intake of the mixed diet is in accordance with the high sensitivity of aminotransferase as indicators of protein adequacy (Garza et al. 1977a).

This short-term $\mathrm{N}$ balance study supports the need to re-evaluate protein recommendations and suggests that a long-term evaluation of egg protein at $0.8 \mathrm{~g} / \mathrm{kg}$ per $\mathrm{d}$ or for a mixed predominantly vegetable diet at $1.0 \mathrm{~g} / \mathrm{kg}$ per $\mathrm{d}$ should be undertaken. Since these intakes are suggested as possible safe recommended allowances for healthy young adults, it is stressed that recommendations for population groups living under environmental conditions prevailing in developing countries must take into account all known factors which affect the host or the capacity of the diet to meet requirements. Considering this fact, the United Nations University World Hunger Programme has undertaken the task of standardizing criteria for performing comparative $\mathrm{N}$-balance studies of protein requirements in children and adults in different parts of the world, consuming diets based on traditional practices.

This study was part of a multicentre project to define protein-energy needs at the global level better and was partially supported by a Grant from the United Nations University World Hunger Programme.

The authors gratefully acknowledge Laboratories Pfizer de Chile for kindly supplying the vitamin-mineral supplement (Polyterra) used in this experiment. The authors also acknowledge the excellent secretarial assistance of Ms Viola Lyon. The collaboration of the subjects involved in the study is also highly appreciated.

\section{REFERENCES}

Association of Official Analytical Chemists (1970). Official Methods of Analysis, 11th. ed. Washington, DC: Association of Official Analytical Chemists.

Calloway, D. H., Odell, A. C. \& Margen, S. (1971). J. Nutr. 101, 775.

Clark, D. H. \& Margen, S. (1971). J. Nutr. 101, 205. 
FAO/WHO (1965). Protein requirements. Report of a Joint FAO/WHO Expert Group. FAO Nutr. Mtgs. Rep. Ser. no. 37; Tech. Rep. Ser. Wld Hlth Org. no. 301.

FAO/WHO (1973). Energy and Protein Requirements. Report of a Joint FAO/WHO Ad Hoc Expert Committee. FAO Nutr. Mtgs. Rep. Ser. no. 52; Tech. Rep. Ser. Wld Hlth Org. no. 522.

Garza, C., Scrimshaw, N. S. \& Young, V. R. (1977a). Br. J. Nutr. 37, 403.

Garza, C., Scrimshaw, N. S. \& Young, V. R. (1977b). J. Nutr. 107, 335.

Jelliffe, D. (1966). Monograph Ser. W.H.O. no. 53.

Kishi, K., Miyatani, S. \& Inoue, G. (1978). J. Nutr. 108, 658.

Lutwak, L. \& Burton, B. T. (1964). Am. J. clin. Nutr. 14, 109.

Markham, R. (1942). Biochem. J. 36, 790.

Ministerio de Economía, Fomento y Reconstrucción (Chile) (1968). Dirección de Estadística y Censos. Encuesta Nacional sobre ingresos familiares.

Ministerio de Salud (Chile) (1976). Encuesta sobre el estado nutricional de la población chilena. Primer Informe: Perfil encuestal.

Morán, C. (1976). Evaluación de Políticas de Alimentación y Nutrición. Thesis (to obtain Licenciado degree). Faculty of Engineering, University of Chile, Chile.

National Academy of Sciences (1974). Recommended Dietary Allowances, 8th. ed. Washington, DC: National Academy of Sciences.

Rand, W. M., Scrimshaw, N. S. \& Young, V. R. (1977). Am. J. clin. Nutr. 30, 1129.

Snedecor, G. W. \& Cochran, W. G. (1967). Statistical Methods, 6th. ed. Ames, Iowa: The Iowa State University Press.

Tietz, N. W. (1970). Fundamentals of Clinical Chemistry, p. 722 [W. B. Saunders editor.] Philadelphia, Pa.

United Nations University World Hunger Programme (1979). Food and Nutrition Bulletin Supplement 1.

Young, V. R., Fajardo, L., Murray, E., Rand, W. M. \& Scrimshaw, N. S. (1975). J. Nutr. 105, 534.

Young, V. R., Taylor, Y. S. M., Rand, W. M. \& Scrimshaw, N. S. (1973). J. Nutr. 103, 1164. 